\title{
Correlation between Individual Characteristics, Workload, and Noise with Work Fatigue
}

\section{Hubungan antara Karakteristik Tenaga Kerja, Beban Kerja dan Kebisingan dengan Kelelahan Kerja}

\author{
Nita Desi Rahmawati, Abdul Rohim Tualeka \\ Departement of Occupational Safety and Health, Faculty of Public Health Universitas Airlangga \\ Campus C Mulyorejo, Surabaya, East Java, Indonesia 60115
}

\begin{abstract}
Introduction: Work fatigue decreases preparedness that raises the risk of workplace accidents. Some of the factors that cause work fatigue are workers characteristics, workload and noise. The purpose of this study is to analyze the correlation between those factors and work fatigue among workers of PT Kerta Rajasa Raya in circulator loom unit. Metods: This is a descriptive observational study that uses a cross sectional approach. This study uses total sampling with a total member of 44 workers. The variables in this study are labor characteristics, including age, gender, years of service, education level, nutritional status, and medical history, which are obtained from questionnaire. Physical workload is assessed based on SNI 7269-2007. Mental workload is measured using NASA-TLX questionnaire. Noise is measured using Sound Level Meter. These variables are the independent variable. The dependent variable, on the other hand, is work fatigue, which is measured by reaction timer. Data are analyzed using Spearman correlation coefficient test (Spearman rho). Results: The results show that 27 workers $(61.4 \%)$ experienced mild work fatigue and one labor $(2.3 \%)$ experienced moderate work fatigue. Conclusion: The study concludes that mental workload has the strongest correlation with work fatigue $(\rho=0.509)$, while medical history has the weakest correlation with work fatigue $(\rho=0.034)$.
\end{abstract}

Keywords: mental workload, noise, reaction timer, work fatigue

\begin{abstract}
ABSTRAK
Pendahuluan: Kelelahan kerja merupakan menurunnya daya atau kapasitas kerja yang berdampak terhadap penurunan kesiagaan sehingga dapat menyebabkan kecelakaan kerja. Beberapa faktor penyebab kelelahan kerja antara lain, karakteristik tenaga kerja, faktor pekerjaan dan kebisingan. Tujuan dari penelitian ini adalah menganalisis karakteristik tenaga kerja, faktor pekerjaan dan kebisingan dengan kelelahan kerja pada tenaga kerja di unit circulator loom PT Kerta Rajasa Raya. Metode: Penelitian ini termasuk dalam penelitian observasional deskriptif dengan pendekatan cross sectional. Sampel yang digunakan dalam penelitian ini adalah total sampling, yaitu sebanyak 44 tenaga kerja. Variabel dalam penelitian adalah karakteristik tenaga kerja yang meliputi umur, jenis kelamin, masa kerja, tingkat pendidikan, status gizi dan riwayat penyakit yang diperoleh dari kuesioner. Beban kerja fisik dinilai berdasarkan SNI 7269-2007, beban kerja mental diukur dengan kuesioner NASA-TLX dan kebisingan diukur dengan Sound Level Meter. Variabel tersebut termasuk dalam variabel independen, sedangan variabel dependennya adalah kelelahan kerja yang diukur dengan reaction timer. Analisis data menggunakan uji koefisien korelasi Spearman (rho Spearman). Hasil: Penelitian menunjukkan bahwa 27 tenaga kerja $(61,4 \%)$ mengalami kelelahan kerja ringan dan seorang tenaga kerja $(2,3 \%)$ mengalami kelelahan kerja sedang. Simpulan: Penelitian ini adalah beban kerja mental memiliki korelasi terkuat dengan kelelahan kerja $(\rho=0,509)$ dan riwayat penyakit memiliki korelasi terlemah dengan kelelahan kerja $(\rho=0,034)$.
\end{abstract}

Kata kunci: beban kerja mental, kebisingan, kelelahan kerja, reaction timer

Author for Correspondence:

Nita Desi Rahmawati

Email: nitadesti31@gmail.com 


\section{INTRODUCTION}

On one hand, the rapid increase in industrialization brings about positive impacts, such as the creation of jobs. On the other hand, such development can also lead to the increase in potential hazards that can affect the safety and health of the workers. Occupational Safety and Health $(\mathrm{OSH})$ is a field of science that focuses on the prevention and reduction of workplace accidents and work-related diseases in the workplace. With the implementation of $\mathrm{OSH}$, workers can perform well in completing its work.

Tarwaka (2013) revealed that a person's performance will be at their optimum point when the work capacity and the workload are in a balance state. It can be said also that the load are neither too low nor excessive. If the workload and work capacity are not in balance, it will result in nonoptimal performance. One of the nonoptimal performance is the occurrence of work fatigue.

There were more than 250 million accidents happened at work every year and 1,2 million workers die because of workplace accidents. One of the highest number of cases of work accidents in Indonesia was in 2013, amounting to 35,917 cases. One of the factors causing work accidents is work fatigue (International Labor Organization, 2013). The results of a study conducted by the Ministry of Manpower in Japan also show that $65 \%$ of workers complained of physical fatigue due to routine work, $28 \%$ complained of mental fatigue, and about $7 \%$ complained of heavy work stress and experienced a sense of exclusion (Mauludi, 2010).

Fatigue according to Tarwaka (2013) is a system in the body that signals if something is causing disorder in the body and that the disorder will recover after a break. Fatigue that occurs in the workplace or commonly referred to as a work fatigue is one of the problems that occur in the workplace, both in the formal and informal sectors. Fatigue can lead to workplace accident, which eventually causes losses to the company. Thus, there is an urgency to give special attention in solving work fatigue problems. If the problems pertain, they may lead to the occurrence of workplace accidents.

One of the factors that play important role in the occurrence of work fatigue ,according to Maurits (2010), is workload. Workload is a burden that the workers have in completing their works. Workload consists of physical, mental, and social workload. Budiman, Husaini and Arifin (2016) show that there is a significant relationship between workload and work fatigue among workers of PT Karias Tabing Kencana.

Beside workload, Maurits (2010) also states that work fatigue can also be caused by work environment. One of the aspects of work environment that can affect workers is noise. Noise is an unwanted sound that can result in temporary and/or permanent deafness and other negative effects such as communication disorders (Suma'mur, 2014). Results from previous research show that $42.8 \%$ of work fatigue is caused by noisy work environment, while the rest is affected by other factors (Hanifa, 2006).

Every workers have the potential of experiencing work fatigue, including those who work at PT Kerta Rajasa Raya circulator loom unit. PT Kerta Rajasa Raya is one of the companies in Sidoarjo that engages in the production of plastic sacks in which one of the unit has a circulator loom unit. Circulator unit is a unit which loom knit plastic yarns into sheets of plastic fabric. The circulator loom unit uses machinery with large power. However, man power is still needed in this unit to distribute the plastic yarns to each machine, and replace and install the yarns to be used in the machines. The distribution is done by expedition workers, while the install is handled by operators. In addition, each worker is responsible for monitoring 3 to 6 machines to estimate the turnover time of yarn uses and the quality of the plastic sack produced.

Based on preliminary study, some circulator loom unit workers complained that their heads feel heavy and that communications are interrupted by the noise in the unit. The last noise intensity data in the circulator loom unit taken by the company reached $96 \mathrm{dBA}$. Compared to the Minister of Manpower Regulation (2018), this noise level exceeds the threshold of the permissible noise.

Therefore, the purpose of this study is to analyze the relationship between workers characteristics, workload, and noise factors with work fatigue among workers in PT. Kerta Rajasa Raya circulator loom unit. 


\section{METHODS}

This is an observational study with descriptive design. This study does not provide a treatment to the object being studied or to the variables of the study. Based on the location of the study, this is a field study, since it was carried out directly in the workplace. According to the time, this is a cross sectional study, since measurements were taken in a certain period. This study was conducted in August 2018.

The population in this study is the entire workers in the circulator loom unit of PT Kerta Rajasa Raya with a total member of 44 workers. In terms of variables, the independent variables are workers' age, sex, years of service, education level, nutritional status, medical history, physical workload, mental workload, and noise; the dependent variable is work fatigue .

Data were collected from direct measurements, questionnaire, and observation. Direct measurements were done on noise variable using Sound Level Meter, nutritional status variable using body mass index (BMI) formula, and work fatigue variable using reaction timer. Data on labor characteristics were obtained through questionnaires. Furthermore, NASA TLX questionnaires were also used to measure mental workload, while data collection on physical work was done through observation. Physical workload was assessed based on Indonesian National Standard (2009) concerning Assessment of Workload Based on the Level of Calorie Needs According to Energy Uses.

Data obtained were then processed in two different analyses: univariate analysis and bivariate analysis. Univariate analysis was used to explain each variable in form of frequency distribution table, while bivariate analysis was used to see the relationship between the two variables: independent and dependent. The test used in this study was the Spearman correlation coefficient statistical test (Spearman rho).

\section{RESULTS}

\section{General Description of PT Kerta Rajasa Raya}

PT Kerta Rajasa Raya is one of the companies in Sidoarjo which produces plastic sacks. This company is located on Jalan Tropodo Nomer 1, Waru, Sidoarjo. The company was, initially, a home industry managed by its owner, the late Mr. Nyoto Santoso. It was established on 23 September 1981 and began producing plastic sacks in mid1982.

PT Kerta Rajasa Raya produces two different sizes of plastic sacks: woven bags with a capacity of $25-50 \mathrm{~kg}$ and jumbo bags with a capacity of $500 \mathrm{~kg}$. The products are not only marketed domestically, but also imported to several countries, such as Malaysia, Australia, Russia, Sri Lanka, Taiwan, South Korea, The United States, Canada and some African countries.

\section{Characteristic of the Workers}

The following are the results of analysis on labor characteristics of the 44 workers in PT Kerta Rajasa Raya circulator loom unit.

Table 1. Workers' Age Distribution of PT Kerta Rajasa Raya Circulator Loom Unit in August 2018

\begin{tabular}{lcc}
\hline Age (years) & $\begin{array}{c}\text { Number of } \\
\text { People }\end{array}$ & Percentage (\%) \\
\hline$\leq 35$ & 2 & 4.5 \\
$36-50$ & 31 & 70.5 \\
$>50$ & 11 & 25 \\
\hline Total & 44 & 100 \\
\hline
\end{tabular}

Based on Table 1, it can be seen that the dominant age group of workers in the unit is $36-50$ years, which is 31 individuals $(70.5 \%)$.

Table 2. Workers' Sex Distribution of PT Kerta Rajasa Raya Circulator Loom Unit in August 2018

\begin{tabular}{lcc}
\hline Sex & $\begin{array}{c}\text { Number of } \\
\text { People }\end{array}$ & Percentage (\%) \\
\hline Male & 14 & 31.8 \\
Female & 30 & 68.2 \\
\hline Total & 44 & 100 \\
\hline
\end{tabular}

Based on Table 2, workers in the unit are mostly females, amounting to 30 indviduals $(68.2 \%)$.

According to Table 3, it can be seen that the workers are dominantly senior high school graduates, which is 22 individuals $(50 \%)$. This education level also refers to those who graduated from vocational high school. 
Table 3. Workers' Education Level Distribution of PT Kerta Rajasa Raya Circulator Loom Unit in August 2018

\begin{tabular}{lcc}
\hline $\begin{array}{c}\text { Level of } \\
\text { Education }\end{array}$ & $\begin{array}{c}\text { Number of } \\
\text { People }\end{array}$ & Percentage (\%) \\
\hline Elementary & 7 & 15.9 \\
Junior high & 15 & 34.1 \\
Senior high & 22 & 50 \\
\hline Total & 44 & 100 \\
\hline
\end{tabular}

Table 4. Workers' Years of Service Distribution of PT Kerta Rajasa Raya Circulator Loom Unit in August 2018

\begin{tabular}{lcc}
\hline $\begin{array}{c}\text { Service } \\
\text { (years) }\end{array}$ & Number of People & Percentage (\%) \\
\hline $15-18$ & 13 & 29.5 \\
$19-22$ & 10 & 22.7 \\
$23-26$ & 7 & 15.9 \\
$27-30$ & 6 & 13.6 \\
$31-34$ & 7 & 15.9 \\
$35-38$ & 1 & 2.3 \\
\hline Total & 44 & 100 \\
\hline
\end{tabular}

Based on Table 4, it is known that the dominant years of service among workers in the circulator loom unit of PT Kerta Rajasa Raya is the 15-18 years group, amounting to 13 individuals $(29.5 \%)$.

Table 5. Workers' Nutritional Status Distribution of PT Kerta Rajasa Raya's Circulator Loom Unit in August 2018

\begin{tabular}{lcc}
\hline $\begin{array}{c}\text { Nutritional } \\
\text { Status }\end{array}$ & $\begin{array}{c}\text { Number of } \\
\text { People }\end{array}$ & Percentage (\%) \\
\hline Normal & 7 & 15.9 \\
Overweight & 17 & 38.6 \\
Obese & 20 & 45.5 \\
\hline Total & 44 & 100 \\
\hline
\end{tabular}

Based on Table 5, it can be seen that the dominant nutritional status of workers in the circulator loom unit of PT Kerta Rajasa Raya is obese, reaching up to 20 individuals $(45.5 \%)$.

According to Table 6, it can be confirmed that most workers (24 individuals, or $54.5 \%$ ) in PT Kerta Rajasa Raya circulator loom unit has no history of acute diseases. The diseases in question are heart diseases, kidney disorders, asthma, low blood pressure, high blood pressure, and/or lung diseases.
Table 6. Workers' Medical History Distribution of of PT Kerta Rajasa Raya's Circulator Loom Unit in August 2018

\begin{tabular}{lcc}
\hline $\begin{array}{c}\text { History of } \\
\text { Accute } \\
\text { Disease }\end{array}$ & $\begin{array}{c}\text { Number of } \\
\text { People }\end{array}$ & Percentage (\%) \\
\hline Present & 20 & 45.5 \\
Absent & 24 & 54.5 \\
\hline Total & 44 & 100 \\
\hline
\end{tabular}

\section{Workload}

Workloads are divided into two: physical workload and mental workload. Moreover, physical workload is categorized further into moderate and high. Similarly, mental workload is also categorized further into low, moderate and high. The followings are results of the analysis on workloads.

Table 7. Workers' Physical Workload Distribution of PT Kerta Rajasa Raya Circulator Loom Unit in August 2018

\begin{tabular}{lcc}
\hline $\begin{array}{c}\text { Physical } \\
\text { Workload }\end{array}$ & $\begin{array}{c}\text { Number } \\
\text { of People }\end{array}$ & $\begin{array}{c}\text { Percentage } \\
(\%)\end{array}$ \\
\hline Moderate & 37 & 84.1 \\
High & 7 & 15.9 \\
\hline Total & 44 & 100 \\
\hline
\end{tabular}

Based on Table 7, the physical workload in PT Kerta Rajasa Raya circulator loom unit is mostly classified as moderate, as mentioned by 37 respondents $(84.1 \%)$.

Similarly, according to Table 8 , it can be seen that the mental workload in the PT Kerta Rajasa Raya circulator loom unit is also mostly classified as moderate (from 23 out of 44 individuals, or $52.3 \%$ ).

Table 8. Workers' Mental Workload Distribution of PT Kerta Rajasa Raya Circulator Loom Unit in August 2018

\begin{tabular}{lcc}
\hline $\begin{array}{c}\text { Mental } \\
\text { Workload }\end{array}$ & $\begin{array}{c}\text { Number of } \\
\text { People }\end{array}$ & Percentage (\%) \\
\hline Low & 5 & 11.4 \\
Moderate & 23 & 52.3 \\
High & 16 & 36.4 \\
\hline Total & 44 & 100 \\
\hline
\end{tabular}


Noise

The measurement of noise intensity is done in two different areas: area of machine operators who are exposed to continuous noise, and area of expedition workers and mechanics who are not exposed to continuous noise. The followings are the results of analysis on noise intensity in PT Kerta Rajasa Raya circulator loom unit.

Table 9. Noise Intensity Distribution of PT Kerta Rajasa Raya Circulator Loom Unit in August 2018

\begin{tabular}{lcc}
\hline \multicolumn{1}{c}{ Section Unit } & Result (dBA) & Percentage (\%) \\
\hline $\begin{array}{l}\text { Machine } \\
\text { operator }\end{array}$ & 103.2 & 68.2 \\
Expedition & 93.1 & 31.8 \\
\hline Mechanics & 900 \\
\hline Total & & 100 \\
\hline
\end{tabular}

Based on Table 9, it is known that noise intensity in the machine operator area is 103.2 $\mathrm{dBA}$ and the noise intensity in the expedition and mechanic area is $93.1 \mathrm{dBA}$.

\section{Work Fatigue}

Work fatigue is measured using reaction timer and divided into three categories: normal, mild fatigue, and moderate fatigue. The following are the results regarding work fatigue in PT Kerta Rajasa Raya circulator loom unit.

Table 10. Workers' Work Fatigue Distribution of PT Kerta Rajasa Raya Circulator Loom Unit in August 2018

\begin{tabular}{lcc}
\hline \multicolumn{1}{c}{ Work Fatigue } & $\begin{array}{c}\text { Number } \\
\text { of People }\end{array}$ & $\begin{array}{c}\text { Percentage } \\
(\boldsymbol{\%})\end{array}$ \\
\hline Normal & 16 & 36.4 \\
Mild fatigue & 27 & 61.4 \\
Moderate fatigue & 1 & 2.3 \\
\hline Total & 44 & 100 \\
\hline
\end{tabular}

According to Table 10, it can be seen that work fatigue experienced the most by workers of PT Kerta Rajasa Raya circulator loom unit lies within the category of mild fatigue (27 workers out of 44 , or $61.4 \%$ ).

\section{Relationship between Workers' Characteristics and Work Fatigue}

Based on Table 11, it is known that most of the circulator loom unit workers of PT Kerta Rajasa Raya are female ranging from 3650 years of age. Most of the workers are senior high school/vocational school graduates with 15-18 years of service. Most of them are obese but without the history of acute disease.

\section{Relationship Between Occupational Factors and Work Fatigue}

Table 12 shows that most of the workers in circulator loom unit of PT Kerta Rajasa Raya is having moderate physical workload and moderate mental workload.

\section{Noise Relationships and Work Fatigue}

Table 13 shows that noise intensity in the expedition and mechanic area of PT Kerta Rajasa Raya circulator loom unit is $93.1 \mathrm{~dB}$. In machine operator area, the noise intensity reaches $103.2 \mathrm{~dB}$.

\section{DISCUSSION}

\section{Characteristics of the Workers}

Most of the workers in circulator loom unit of PT Kerta Rajasa Raya are in an age group of 36-50 years. In general, those range of age is classified as productive age. PT Kerta Rajasa Raya began hiring employees as young as 18 years old, but the company does not regulate the age limit to end an employment. The age of each individual has an influence on his/her performance or activity in daily life. The older the person is, the more physiological change he/she will experience. Those physiological changes may include the declining of respiratory function, hearing, and visual acuity, memory loss, and the ability to make a decision (Tarwaka, 2010).

Workers in the unit are mostly female. PT Kerta Rajasa Raya has an assumption that female is more thorough, skillful, and diligent in terms of work completion compared to their male counterparts. Although in terms of physical strength, Suma'mur (2009) states that generally, females only have two thirds of the physical strength of males. 
Table 11. Relationship Between Characteristics of the Workers and Work Fatigue among Workers in the Circulator Loom Unit of PT Kerta Rajasa Raya in August 2018

\begin{tabular}{|c|c|c|c|c|c|c|c|c|c|c|}
\hline \multirow{3}{*}{$\begin{array}{c}\text { Characteristics of the } \\
\text { Workers }\end{array}$} & \multirow{3}{*}{ Group } & \multicolumn{6}{|c|}{ Work Fatigue } & \multirow{2}{*}{\multicolumn{2}{|c|}{ Total }} & \multirow{3}{*}{$\begin{array}{l}\text { Coefficient } \\
\text { Contingency }\end{array}$} \\
\hline & & \multicolumn{2}{|c|}{ Normal } & \multicolumn{2}{|c|}{ Mild } & \multicolumn{2}{|c|}{ Moderate } & & & \\
\hline & & $\mathrm{n}$ & $\%$ & $\mathrm{n}$ & $\%$ & $\mathrm{n}$ & $\%$ & $\mathbf{N}$ & $\%$ & \\
\hline \multirow{3}{*}{ Age } & $\leq 35$ & 1 & 50 & 1 & 50 & 0 & 0 & 2 & 100 & \multirow{3}{*}{0.256} \\
\hline & $36-50$ & 13 & 41.9 & 18 & 58,1 & 0 & 0 & 31 & 100 & \\
\hline & $>50$ & 2 & 18.2 & 8 & 72.7 & 1 & 9.1 & 11 & 100 & \\
\hline \multirow{2}{*}{ Sex } & Male & 7 & 50 & 7 & 50 & 0 & 0 & 14 & 100 & \multirow{2}{*}{0.206} \\
\hline & Female & 9 & 30 & 20 & 66.7 & 1 & 3.3 & 30 & 100 & \\
\hline \multirow{3}{*}{ Level of education } & $\begin{array}{l}\text { Elementary } \\
\text { school }\end{array}$ & 1 & 14.3 & 6 & 85.7 & 0 & 0 & 7 & 100 & \multirow{3}{*}{-0.111} \\
\hline & $\begin{array}{l}\text { Junior high } \\
\text { school }\end{array}$ & 6 & 40 & 9 & 60 & 0 & 0 & 15 & 100 & \\
\hline & $\begin{array}{c}\text { Senior high } \\
\text { school }\end{array}$ & 9 & 40.9 & 12 & 54.5 & 1 & 4.5 & 22 & 100 & \\
\hline \multirow{6}{*}{ Years of service } & $15-18$ & 4 & 30.8 & 9 & 69.2 & 0 & 0 & 13 & 100 & \multirow{6}{*}{0.086} \\
\hline & $19-22$ & 4 & 40 & 6 & 60 & 0 & 0 & 10 & 100 & \\
\hline & $23-26$ & 5 & 71.4 & 2 & 28.6 & 0 & 0 & 7 & 100 & \\
\hline & $27-30$ & 2 & 33.3 & 4 & 66.7 & 0 & 0 & 6 & 100 & \\
\hline & $31-34$ & 0 & 0 & 6 & 85.7 & 1 & 14.3 & 7 & 100 & \\
\hline & $35-38$ & 1 & 100 & 0 & 0 & 0 & 0 & 1 & 100 & \\
\hline \multirow{3}{*}{ Nutritional status } & Normal & 5 & 71.4 & 2 & 28.6 & 0 & 0 & 7 & 100 & \multirow{3}{*}{0.308} \\
\hline & Overweight & 6 & 35.3 & 11 & 64.7 & 0 & 0 & 17 & 100 & \\
\hline & Obese & 5 & 25 & 14 & 70 & 1 & 5 & 20 & 100 & \\
\hline History of Acute & Present & 8 & 40 & 11 & 55 & 1 & 5 & 20 & 100 & \multirow{2}{*}{0.034} \\
\hline Disease & Absent & 8 & 33.3 & 16 & 66.7 & 0 & 0 & 24 & 100 & \\
\hline Total & & 16 & 36.4 & 27 & 61.4 & 1 & 2.3 & 44 & 100 & \\
\hline
\end{tabular}

Table 12. Relationship Between Workload and Work Fatigue among Workers in the Circulator Loom Unit of PT Kerta Rajasa Raya in August 2018

\begin{tabular}{|c|c|c|c|c|c|c|c|c|c|c|}
\hline \multirow{3}{*}{ Workload } & \multirow{3}{*}{ Group } & \multicolumn{6}{|c|}{ Work Fatigue } & \multirow{2}{*}{\multicolumn{2}{|c|}{ Total }} & \multirow{3}{*}{$\begin{array}{l}\text { Coefficient } \\
\text { Contingency }\end{array}$} \\
\hline & & \multicolumn{2}{|c|}{ Normal } & \multicolumn{2}{|c|}{ Mild } & \multicolumn{2}{|c|}{ Moderate } & & & \\
\hline & & $\mathbf{n}$ & $\%$ & $\mathbf{n}$ & $\%$ & $\mathbf{n}$ & $\%$ & $\mathbf{N}$ & $\%$ & \\
\hline \multirow{2}{*}{ Physical Workload } & Moderate & 12 & 32.4 & 24 & 64.9 & 1 & 2.7 & 37 & 100 & \multirow{2}{*}{-0.193} \\
\hline & High & 4 & 57.1 & 3 & 42.9 & 0 & 0 & 7 & 100 & \\
\hline \multirow{3}{*}{ Mental Workload } & Low & 5 & 100 & 0 & 0 & 0 & 0 & 5 & 100 & \multirow{3}{*}{0.509} \\
\hline & Moderate & 9 & 39.1 & 14 & 60.9 & 0 & 0 & 23 & 100 & \\
\hline & High & 2 & 12.5 & 13 & 81,3 & 1 & 6.3 & 16 & 100 & \\
\hline Total & & 16 & 36.4 & 27 & 61.4 & 1 & 2.3 & 44 & 100 & \\
\hline
\end{tabular}

Table 13. Relationship Between Noise and Work Fatigue among Workers in the Circulator Loom Unit of PT Kerta Rajasa Raya in August 2018

\begin{tabular}{|c|c|c|c|c|c|c|c|c|c|}
\hline \multirow{3}{*}{$\begin{array}{l}\text { Noise Intensity } \\
\text { (dBA) }\end{array}$} & \multicolumn{6}{|c|}{ Work Fatigue } & \multirow{2}{*}{\multicolumn{2}{|c|}{ Total }} & \multirow{3}{*}{$\begin{array}{c}\text { Coefficient } \\
\text { Contingency }\end{array}$} \\
\hline & \multicolumn{2}{|c|}{ Normal } & \multicolumn{2}{|c|}{ Mild } & \multicolumn{2}{|c|}{ Moderate } & & & \\
\hline & $\mathbf{n}$ & $\%$ & $\mathbf{n}$ & $\%$ & $\mathbf{n}$ & $\%$ & $\mathbf{N}$ & $\%$ & \\
\hline 93.1 & 7 & 50 & 7 & 50 & 0 & 0 & 14 & 100 & 0206 \\
\hline 103.2 & 9 & 30 & 20 & 66.7 & 1 & 3.3 & 30 & 100 & 0.206 \\
\hline Total & 16 & 36.4 & 27 & 61.4 & 1 & 2.3 & 44 & 100 & \\
\hline
\end{tabular}

The dominant level of education of the workers is in the range of senior high school/equivalent graduates. PT Kerta Rajasa
Raya has the minimum criteria for the level of education of its workers, which is senior high school/equivalent. Nevertheless, the company 
still hires workers below the minimum education standard because these workers are senior workers who are employed before the regulation was made. The said regulation was made in 2008. Maurits (2010) states that the higher the level of the workers education, the higher the cognitive ability they have. They have broader span of thinking and be more initiative, so it is easier for these workers to find better and more efficient ways to get their work done.

The workers' dominant years of service is in the group of 15-18 years. According to the circulator loom unit supervisor, this is because the work done in the circulator loom unit is relatively light so that the workforce is considered capable of completing work. The relatively light work also influence the low level of company's employee turnover. Suma'mur (2009) states that workers with long years of services have better adaptability to various problems and situations.

In terms of nutritional status, workers in the circulator loom unit are mostly obese. Obesity is a state in which excess fat is stored in adipose tissue. This condition may interfere with one's health and increase the risk of several diseases, such as type 2 diabetes, high blood pressure, heart disease, and stroke (Adriani and Bambang, 2012). PT Kerta Rajasa Raya does not provide meal during breaks, so some workers bring their own meals. This uncontrolled meal is one of the factors contributing to the high number of obesity. Based on interviews with the workers, they do not exercise regularly. The workers consider their physical work can already be considered as exercise.

The fact that most workers are obese is in contrast with the finding that most of them do not have history of acute diseases. Twenty-four workers in circulator loom unit have no history of such diseases. The diseases in question are heart disease, kidney disorders, asthma, low blood pressure, high blood pressure, and lung disease. This information is only based on interviews and questionnaires, and there is no valid medical evidence regarding the workers' health condition.

\section{Workload}

Circulator loom unit are divided into three sections: machine operator, expedition, and mechanical parts (maintenance) section.
The task of workers in the machine operator section is operating and supervising the engine, and replacing plastic yarns on shuttle machines and rack machines. Workers in the expedition section is responsible to prepare baskets of plastic yarns on the pallet, prepare handjacks (tool used to send plastic yarns to each machine), move the basket of plastic yarns on the pallet to the handjack, send plastic yarns to each machine, and take out empty baskets from each machine. Mechanical or maintenance workers's main jobs are overseeing all operating machines thoroughly, cleaning shuttle plastic yarns, and repairing damages in the machines.

Aside from the physical workload, workers in the circulator loom unit of PT Kerta Rajasa Raya also have mental workload. The workers have mental burden in dealing with operation of the machines they use, estimating the time to replace plastic yarns, and dealing with quality of the plastic sack produced. The mental workload of PT Kerta Rajasa Raya circulator loom unit workers is classified as moderate $(52.3 \%)$, according to NASA-TLX questionnaire. The workers are required to meet the required targeted orders. In addition, the workers are also required to make estimates and ensure that the order criteria are properly met. The dominant factor contributing to the mental workload felt by the workers is, surprisingly, physical needs. In completing their works, the workers do a lot of physical activity, such as putting plastic yarns on the machine, picking up and replacing plastic yarns baskets for and from the machines, and surveying the area to make sure that machines are in good condition. These repetitive activities can accelerate fatigue.

\section{Noise}

The measurement of noise intensity in PT Kerta Rajasa Raya's circulator loom unit is divided based on two areas: machine operator area, which is exposed to continuous noise, and expedition and mechanical area, which are not exposed to continuous noise. Noise intensity in the machine operator area is measured 103.2 $\mathrm{dBA}$, while in the mechanical and expedition area is $93.1 \mathrm{dBA}$. The results in both areas exceed the allowed noise threshold. Based on the Permenaker Nomor 5 Tahun 2018 concerning Occupational Safety and Health $(\mathrm{OSH})$, the permissible noise in a workplace is no more than $85 \mathrm{~dB}$. 


\section{Work Fatigue}

Work fatigue measurement using reaction timer on workers in circulator loom of PT Kerta Rajasa Raya shows that 27 workers $(61.4 \%)$ experience mild work fatigue. Moderate work fatigue is only experienced by one worker $(2.3 \%)$. The analysis shows that the workers who experienced the most work fatigue are those who work as machine operators: 16 people experience normal work fatigue and 1 person experience moderate work fatigue. The results of the study show that measures should be taken to overcome work fatigue experienced by workers. Eventhough the experienced work fatigue is still considered mild, it can become worse if no preventive and corrective measures are being taken. It also has the potential to increase work accidents on workers.

\section{Relationship Between Characteristics of Workers and Work Fatigue}

The relationship between workers' age and work fatigue has a correlation coefficient value of 0.256 , indicating a weak correlation. The positive value can be interpreted that as a person grows older, work fatigue will also be easier to occur. This is in line with the study of Deyulmar, Suroto and Wahyuni (2018) which states that there is a relationship between age and work fatigue in opaque workers in Ngadikerso Village of Semarang Regency. Nindya, et al. (2013) reveals that respondents of $>40$ years of age experience fatigue. This fatigue lowers their working capacity down to $60 \%-80 \%$ even though they are still in the productive age. This can happen because as a person grows older, the organs will undergo degeneration, decreasing the ability to do their works, such as vision, hearing, and reaction time.

The relationship between sex and work fatigue has a correlation coefficient of 0.206. This value means that the relationship is considered as weak. This positive value also indicates that female workers will apt to experience work fatigue. Study conducted by Sihontang (2004) states that females have a greater frequency to experience work fatigue than males due to females' higher frequency of having emotional fatigue.

The relationship between the level of education and work fatigue has a correlation coefficient of -0.111 , meaning that the relationship between the two variables is very weak and inversely proportional. It can also be said that the higher the level of education is, the lower the work fatigue's likeliness to occur. Soasa (2013) study states that there is a relationship between education level and work fatigue among loading and unloading workers at Manado Port. Workers who experience fatigue in work are mostly elementary school graduates. Workers with low education level have less awareness of the impact and risk of their work. Therefore, they do not have knowledge of Occupational Safety and Health $(\mathrm{OSH})$ in the workplace.

The relationship between years of service and work fatigue has a correlation coefficient of 0.086 . This value indicates that the relationship between the two variables is very weak. This value is also marked positive, which means that the longer the years of service a worker has, the more work fatigue he/she will experience. Although it can be interpreted as such, the two variables have a very weak relationship so that the long years of service does not significantly make a person more prone to work fatigue.

The relationship between nutritional status and work fatigue has a correlation coefficient of 0.308 which indicates that the relationship is positively weak. This study is in line with Triana, Ekawati and Wahyuni (2017) who suggest that there is a relationship between nutritional status and work fatigue in mechanical workers at PT X Plant Jakarta. Workers with poor nutritional status will tend to experience more work fatigue. Obese workers have less agility due to the excess of weight. Individuals with excessive weigth are easily tired when performing physical activities under fast rhythm.

The relationship between history of acute diseases and work fatigue has a correlation coefficient of 0.034 which indicates that the relationship between the two is very weak. Study conducted by Gurusinga, Camelia and Purba (2015) explaines that there is no relationship between medical history and work fatigue in PT PN VII sugar factory workers in 2013. A person's health level was divided into two, namely physical health and mental or psychological health. A person's mental health is also influential to the occurrence of work fatigue. Individuals often have something to think about. These thoughts can become a burden and may interfere with physical condition. This unwell health condition 
contributes to work fatigue on workers (Mukhlasin, 2017).

\section{Relationship Between Workload and Work Fatigue}

The relationship between physical workload with fatigue has a correlation coefficient of -0.193 , denoting that the lower the physical workload is, the greater the fatigue. According to the study of Setyowati, Shaluhiyah, \& Widjasen (2014), there is no significant relationship between physical workload and the incidence of work fatigue in the workers in the furniture industry. Repetitive work makes the work feels monotonous. Monotonous work leads to lower production of adrenaline, which relates to depression, irritability, and psychosomatic complaints (Maurits, 2010).

The relationship between mental workload and work fatigue has a correlation coefficient of 0.509 which indicates that there is a moderate and positive relationship. Most of the mental workload felt by PT Kerta Rajasa Raya circulator loom workers is dominated by physical needs. It is undeniable that the work done by workers also require considerable physical force, such as replacing and installing plastic yarns on the machine. In addition to physical force, machine operators are also in charge of overseeing more than one machine, maintaining the quality of plastic sacks, and estimating how long a machine can complete the targeted order. The type of work in the circulator loom unit is a job that must be carried out repeatedly over a long period of time. This type of job makes the workers vulnerable to experiencing boredom. Workers who experience boredom can also experience work fatigue because they tend to underestimate the load they can handle. As a result, the workers will experience a decrease in preparedness which will eventually have impact on workplace accidents. According to Koesyanto (2008), workers often feel tired when they do nothing. This can be caused by a sense of responsibility, anxiety, concern, and problems that they currently faced.

\section{Relationship Between Noise and Work Fatigue}

The relationship between noise and work fatigue has a correlation coefficient value of
0.206 . This value indicates that there is a weak relationship between noise and work fatigue. The relationship between noise and work fatigue is a positive one, meaning that the higher the noise intensity is, the greater the work fatigue can occur. The results of this study are in line with the results found by Hayati (2012) which reveals that there is a relationship between noise level and work fatigue in the ringframe workers of PT Kusuma Putra Santosa Karanganyar.

Noise is defined as unwanted sound. Some sound stimulus that is received by the ear can cause an uncomfortable sensation of ringing. The disturbing sound sensation will strengthen the inhibition system in the thalamus (Hayati, 2012). Suma'mur (2014) also argues that fatigue is regulated centrally in the brain. In the central nervous system, there is a system of activation and inhibition. Both of these systems offset each other but sometimes one of them is more dominant in accordance with needs. The activation system is sympathetic, whereas inhibition is parasympathetic. In order for balance the two systems, the workers must be in a condition that provides stabilization to the body.

Based on interviews with workers, they are accustomed to the noise produced by the machinery. This will be doubled if they do not use personal protective equipment (PPE) such as earplug or earmuff to reduce the noise.

\section{CONCLUSION}

From this study it can be concluded that most of the workers of PT Kerta Rajasa Raya circulator loom unit are female and between 3650 years of age. Most of the workers are high school/vocational school graduates, have 15-18 years of service, obese, and have no history of acute disease. The physical workload and the mental workload of the workers are categorized as moderate and most workers experience mild fatigue. Noise in the circulator loom unit exceeds the allowed noise according to Minister of Manpower Regulation (2018). Work fatigue of most workers falls under mild category.

The relationship between years of service and medical history with work fatigue is very weak and positive. In addition, the relationship between education level and physical workload with work fatigue is also very weak but negative. The relationship between age, sex, nutritional status, and noise with work fatigue is 
weak and positive. Meanwhile, the relationship between mental workload and work fatigue is moderate and positive.

\section{ACKNOWLEDGMENT}

The author thank God for His blessings in the completion of the research. My deep and sincere gratitude also goes to the research supervisor, Dr. Abdul Rohim Tualeka, Drs., M.Kes, for his guidance, inspiration, and motivation. My special appreciation also goes to Prof. Dr. Tri Martiana, dr., M.S as the Dean of the Faculty of Public Health Universitas Airlangga. I am extending my heartfelt gratitude for Dr. Diah Indriani, S.Si., M.Si, Putri Ayuni Alayyanur, S.KM., M.KKK, and dr. Siswanto, who taught me to carry out research. Your advice for this research is invaluable. I am also much obliged to Hernanda Bagus, S.Psi as Human Resources Manager in PT Kerta Rajasa Raya and Ilham as circulator loom supervisor. Thank you for your help and the opportunity to be in your company. I also thank my family and friends for their continuing support and prayer.

\section{REFERENCES}

Adriani, M. and Bambang, W. (2012) Introduction to Community Nutrition. Jakarta: Kencana Prenada Media Group.

Budiman, A., Husaini and Arifin, S. (2016) 'Relationship Between Age and Workload Index with Fatigue in Workers at PT Karias Tabing Kencana', Jurnal Berkala Kesehatan, 1(2), pp. 121-129.

Deyulmar, B. A., Suroto and Wahyuni, I. (2018) 'Analysis of Factors Associated with Fatigue in Workers of Opak Crackers in Ngadikerso Village, Semarang Regency', Jurnal Kesehatan Masyarakat FKM Undip, 6(4), pp. 278285.

Gurusinga, D., Camelia, A. and Purba, I. G. (2015) 'Analysis Factors Associated with Fatigue in Operators of Sugar Factory in PT. PN VII Cinta Manis 2013', Jurnal Ilmu Kesehatan Masyarakat, 6(2), pp. 83-91.

Hanifa, T. Y. U. (2006) The Effect of Noise Against Fatigue in the Brumbung Timber Processing Industry Perum Perhutani Semarang in 2005. Undergraduate Thesis. Semarang: Faculty of Sports
Sciences, Universitas Negeri Semarang.

Hayati, F. N. (2012) The Correlation of Noise Level and Work Fatigus in the Ringframe Division's Employees of PT. Kusumaputra Santosa Karanganyar. Undergraduate Thesis. Surakarta: Faculty of Medicine, Universitas Sebelas Maret.

Indonesian National Standard (2009) Assessment of Workload Based on the Level of Calorie Needs According to Energy Expenditures. Jakarta: Indonesian National Standard.

International Labor Organization (2013) Occupational Health and Safety. Geneva: International Labor Organization.

Koesyanto, H. (2008) 'Relationship between Work Loads with Extension of Teaching Work at Basic School Teachers in West Semarang Academic Year 2006/2007, Kesehatan Masyarakat (KESMAS), 3(2), pp. 115-125.

Mauludi, M. N. (2010) Factors Associated With Fatigue in Workers In PBD (Paper Bag Division) Cement Bag Production Process PT. Indocement Tunggal Prakarsa Tbk Citeureup-Bogor Year 2010. Undergraduate Thesis. Jakarta: Faculty of Medicine and Health Sciences, Universitas Islam Negeri Syarif Hidayatullah.

Maurits, L. S. K. (2010) Glance About Exhaustion of Work. Yogyakarta: Amara Books.

Minister of Manpower of the Republic of Indonesia (2018) Number 5 Year 2018. Concerning Occupational Safety and Health Work Environment. Jakarta: Ministry of Manpower Republic of Indonesia.

Mukhlasin (2017) 'Risk Factors of Work Fatigue in Gas Station Operators in Grogol District, Cilegon City', Faletehan Health Journal, 4(3), pp. 143-148.

Setyowati, D. L., Shaluhiyah, Z. and Widjasen, B. (2014) 'Factors Caused Fatigue among Furniture Workers', Jurnal Kesehatan Masyarakat Nasional, 8(8), pp. 386-392.

Sihontang, I. N. (2004) 'Employees' Burnout in Relation to Perception toward Psychological Work Environment and Sex', Jurnal PSYCHE, 1(1), pp. 9-17.

Soasa, M. (2013) Individuals with Fatigue Factor Relationships Work Stevedoring in Port of Manado. Undergraduate 
Thesis. Manado: Faculty of Public Health, Universitas Sam Ratulangi.

Suma'mur, P. (2009) Corporate Hygiene and Occupational Health. Jakarta: CV Sagung Seto.

Suma'mur, P. K. (2014) Corporate Hygiene and Occupational Health. 2nd edn. Jakarta: CV Sagung Seto.

Tarwaka (2010) Industrial Ergonomics: Basics of Ergonomics Knowledge and Applications at Work. Surakarta: UNIBA Press.

Tarwaka (2013) Industrial Ergonomics: Basics of Ergonomics Knowledge and Applications at Work. Surakarta: Harapan Press.

Triana, E., Ekawati and Wahyuni, I. (2017) 'The Correlation between Nutritional Status, Sleep Duration, Work Period and Workload with Work Fatigue for Mechanics at PT X Plant Jakarta', Jurnal Kesehatan Masyarakat (e-Journal) FKM Undip, 5(5), pp. 146-155. 